\title{
Infection Risk Potential of South American Spongospora subterranea f.sp. subterranea Root Gall and Tuber Lesion Inoculum on Potato (Solanum tuberosum ssp. tuberosum)
}

\author{
Rebecca D. Gau • Ueli Merz • Richard E. Falloon
}

Published online: 1 November 2014

(C) The Potato Association of America 2014

\begin{abstract}
Spongospora subterranea f. sp. subterranea causes the potato diseases powdery scab on tubers and galls on roots, and occurs in most potato production areas worldwide. The pathogen was probably introduced to Europe from South America in the 16th century. Three different genotype clusters have been found worldwide: the genetically variable groups from South America (native), and, in contrast, the nearly clonal group outside South America (invasive). An inoculation experiment was carried out with the long-day potato host 'Agria' comparing three different native Spongospora resting spore inocula with an invasive one, to determine the infection risk potential on a widely grown potato subspecies. All inocula led to root infection. Invasive tuber lesion sporosori from 'Agria' produced the greatest amount of infection, whereas the tuber lesion inoculum from the Venezuelan S. tuberosum ssp. tuberosum host and the root gall inoculum from the Colombian S. phureja host caused the least infections. The inoculum genotypes corresponded to all of the three previously described groups. Most root galls showed the invasive group type, independent of the inoculum. These results suggest that the most successful invasive genotype is still present in native pathogen populations and emphasize the need for continued quarantine vigilance to prevent new virulent recombinants of the pathogen.
\end{abstract}

R. D. Gau $\cdot$ U. Merz $(\bowtie)$

Plant Pathology, Institute of Integrative Biology, ETH Zurich, 8092 Zurich, Switzerland

e-mail: ueli.merz@usys.ethz.ch

R. E. Falloon

New Zealand Institute for Plant and Food Research Limited, Lincoln, New Zealand

R. E. Falloon

Bio-Protection Research Centre, Lincoln University, Lincoln, New Zealand
Resumen Spongospora subterranea f. sp. Subterranean causa las enfermedades de la papa de la roña polvorienta en tubérculos y agallas en la raíz, y se presenta en la mayor parte de las áreas productoras de papa en todo el mundo. Posiblemente el patógeno se introdujo a Europa de América del Sur, en el siglo XVI. En el mudo se han encontrado tres diferentes grupos de genotipos: los grupos genéticamente variables de Sudamérica (nativos) y, en contraste, el grupo casi clonal fuera de América del Sur (invasor). Se efectuó un experimento de inoculación con la papa hospedera de día largo "Agria" comparando inóculo de esporas en reposo de tres diferentes Spongospora nativas con una invasora, para determinar el riesgo potencial de infección en una subespecie ampliamente cultivada de papa. Todos los inocula condujeron a infección de la raíz. Los sporosori invasores de lesión de tubérculo de "Agria" produjeron la mayor cantidad de infección, mientras que el inóculo de la lesión del tubérculo de la hospedera venezolana $S$. tuberosum ssp. tuberosum, y el inóculo de las agallas de la raíz de la hospedera colombiana $S$. phureja causó las menores infecciones. El inóculo de los genotipos correspondió a los tres grupos descritos previamente. La mayoría de las agallas de la raíz mostraron el tipo del grupo invasor, independientemente del inóculo. Estos resultados sugieren que el genotipo invasor de mayor éxito aún está presente en poblaciones patogénicas nativas y se enfatiza la necesidad de vigilancia cuarentenaria continua para prevenir nuevas recombinaciones virulentas del patógeno.

Keywords Powdery scab · Invasive species · Genetic variability $\cdot$ Global seed trade $\cdot$ Quarantine measures

\section{Introduction}

Spongospora subterranea f. sp. subterranea (Sss: Cercozoa, Plasmodiophoridae), is a soilborne, obligate biotrophic 
pathogen, which causes diseases throughout the major potato (Solanum tuberosum) growing regions of the world. These are powdery scab, an important blemish disease of potato tubers; and root galls on potato roots. Both diseases can cause severe losses in potato production and processing (Merz and Falloon 2009; Shah et al. 2012).

Sporosori of the pathogen ('spore balls') each containing many resting spores, are formed in tuber lesions and roots galls (Fig. 1a-c). From resting spores, biflagellate primary zoospores (Fig. 1d) emerge and can travel short distances in moist soil to reach and infect the host tissue (Merz and Falloon 2009). Plasmodia of Sss are formed in infected host cells, which proliferate to zoosporangia from which secondary zoospores emerge to cause further infections. Completing the life cycle, plasmodia can also develop into sporosori and resting spores, which contain the primary zoospores. Although it has been suggested that resting spores may be the product of sexual reproduction (Braselton 1995), the role of sexual and asexual reproduction in the life cycle of Sss still remains to be elucidated. The resting spores are highly resistant to environmental stresses and pesticides. Thus, once a field is contaminated by $S s s$ sporosori, it is likely to remain infectious for many years (de Boer 2000).
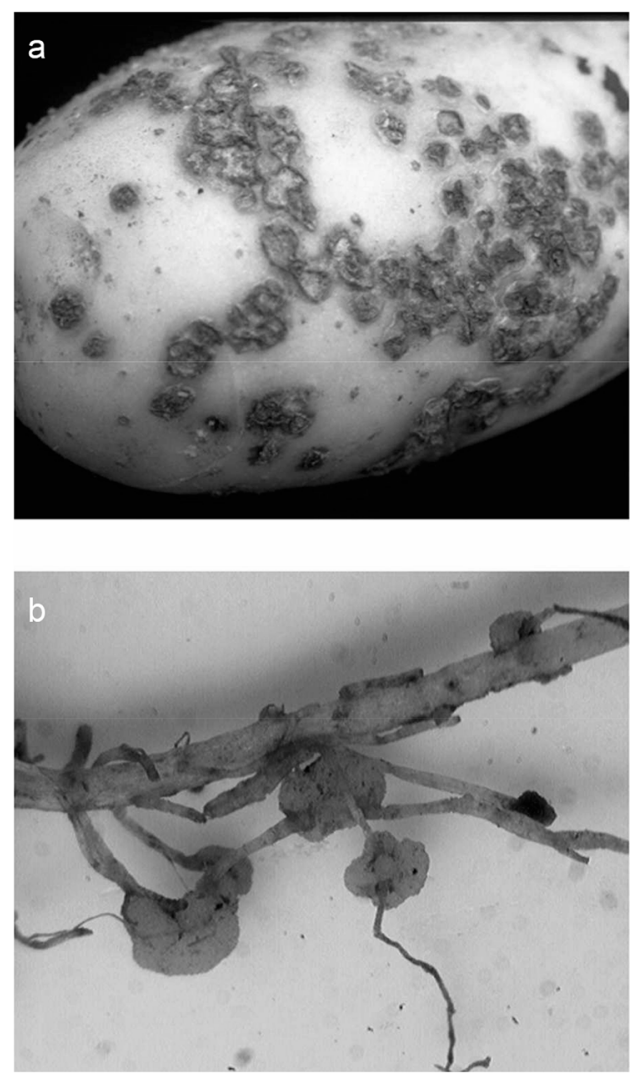

Fig. 1 a Potato tuber with powdery scab lesions. b Pale, immature root galls. c Scanning electron micrograph of a Spongospora subterranea $\mathrm{f}$. sp. subterranea sporosorus, consisting of numerous single resting spores,
The life cycle of Sss prevents natural long-distance dispersal. An invasion scenario for Sss was suggested by Gau et al. (2013): The pathogen probably first reached Europe carried by humans, when the conquistadors brought the potato from South America, which is likely to be the native region both of the host and Sss. After a few more introduction events, Sss established in Europe and was cut off from South America. Further spread occurred only from Europe to all other regions in the world via infected seed tubers. The pathogen must have adapted successfully to new climatic conditions despite low genetic variability and strong bottlenecks. Although introductions of new Sss strains from South America might be possible, no substantial exchange between South America and the rest of the world occurs in modern seed potato trade (Rabobank 2009). This has resulted in geographical separation of Sss populations in native and invasive regions, represented by their differences in genetic variability. Under these circumstances the risk of increasing genetic variability of Sss in invasive regions is likely to be low.

There are no potato cultivars with complete resistance to Sss, or effective pesticides against the pathogen, so the only way to control the pathogen currently is prevention in the form of planting certified (non-infested) seed. Further, enforcement of quarantine measures is necessary to avoid new
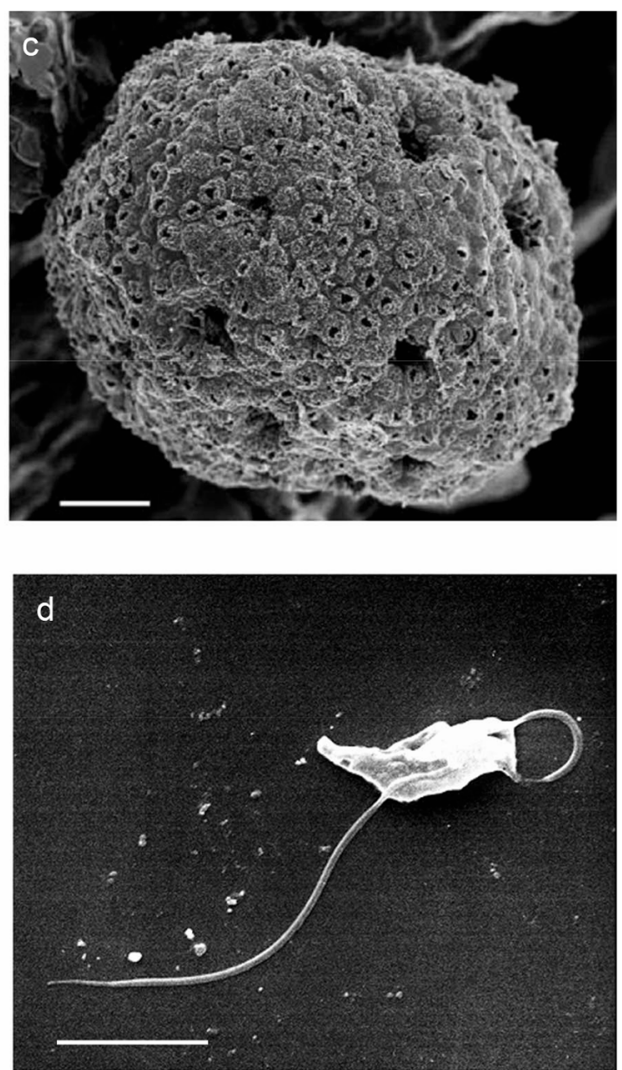

some with openings for zoospore release (bar $=10 \mu \mathrm{m}$ ). d Scanning electron micrograph of a primary zoospore of the pathogen, with two flagella $(\mathrm{bar}=5 \mu \mathrm{m})$ 
introductions, especially from South America. Until now, a global quarantine concept does not exist and individual countries have definitions of tolerance limits for the amount of disease caused by Sss on seed tubers. If newly introduced populations of Spongospora are able to establish in Europe, this would pose threats to all other regions worldwide, because Europe is the seat of the largest export seed potato producers in the world (Rabobank 2009). Europe consists mostly of temperate regions with long days. To decide which quarantine measures are efficient and applicable, the potato/ Sss host-pathogen interaction under long day conditions must be understood.

Among the edible potato varieties, there are three (sub-) species, which are of economic importance and which are hosts of Sss: In some Andean regions of South America, mainly short day potato plants $(S$. tuberosum ssp. andigena $(A n)$ and $S$. phureja $(P h)$ ) are cultivated, whereas in other regions the long day plant $S$. tuberosum ssp. tuberosum (Tu) is also cultivated, which is the most widely grown potato subspecies worldwide. Striking differences in susceptibility to tuber and root infection of $T u$ cultivars have been observed by Schwaerzel (2002) and Falloon et al. (2003) who assessed both diseases, although none of the varieties were completely resistant. A recently published population genetics study by Gau et al. (2013) indicated genetic sub-structuring in the tested Sss populations according to the location and host tissue from which these samples were obtained. South American samples from root galls, mainly collected on $P h$, formed one group (A), and samples from tuber lesions, mainly on $A n$ and $T u$, formed another group (B). Samples from the rest of the world belonged to a third group (C) with a highly clonal genetic structure and no host tissue differentiation.

Climatic conditions may interfere with the infection process and development of host and pathogen, which challenges results drawn from field trials when comparing the performance of potato host species with different photoperiodic needs. Torres et al. (1995) and Rodriguez et al. (2009) performed trials in South America comparing short day and long day potato plants. Both of these research groups reported greater susceptibility to powdery scab of some $T u$ cultivars than previously reported. These field trials, however, were conducted at altitudes above 3,000 m under short day conditions where the performance of long dayadapted $T u$ hosts is likely to be different from their performance under their preferred climate conditions. Alternatively, the presence of local pathotypes of Sss was suggested, which may differ in virulence (Torres et al. 1995; Rodriguez et al. 2009). Trials are usually conducted in naturally contaminated soil or soil or sand artificially inoculated with local SsS sporosorus material.

Studies under controlled climate conditions of how different Sss inocula interact with the economically most important potato host (subspecies $T u$ ), have not been previously reported. Such data would help to define risk scenarios for the evaluation of quarantine measures with the goal to prevent further spread and new introductions of the pathogen.

The present study aimed to assess the ability of different Sss sporosorus inocula to cause disease symptoms on the $T u$ potato host, and to compare the genetics of the inocula with their infection products on host roots and tubers. A bioassay (Merz et al. 2004) was used in an inoculation experiment. Root gall and tuber lesion inoculum from South America (native) and Switzerland, (invasive) obtained from different potato hosts, was applied to $T u$ potato host ('Agria'). The severity of root galling on test plants was assessed and a root gall index was calculated. Inoculum and sporosori, collected from infected plants, were genetically analysed.

\section{Materials and Methods}

\section{Cultivation and Preparation of Tissue Cultured Potato Plantlets}

Stem cuttings of 'Agria' (Solanum tuberosum ssp. tuberosum) were cultivated in agar tissue cultures as described in Merz et al. (2004), and sub-cultured every 4 weeks. The roots of 4 week-old plantlets were washed free of agar medium with tap water, trimmed to a length of $60 \mathrm{~mm}$, and then were transferred (two per dish) to Petri dishes (diam. $75 \mathrm{~mm}$, depth $30 \mathrm{~mm}$, painted black outside) with lids.

\section{Nutrient Solution (NS)}

Nutrient solution was prepared as a concentrated stock solution. One liter contained $7.22 \mathrm{~g}$ calcium nitrate tetra hydrate $\left(\mathrm{Ca}\left(\mathrm{NO}_{3}\right)_{2}\right), 2.53 \mathrm{~g}$ of potassium nitrate $\left(\mathrm{KNO}_{3}\right), 2.46 \mathrm{~g}$ of magnesium sulphate hepta hydrate $\left(\mathrm{MgSO}_{4} \times 7 \mathrm{H}_{2} \mathrm{O}\right), 400 \mathrm{mg}$ of ammonium nitrate $\left(\mathrm{NH}_{4} \mathrm{NO}_{3}\right), 230 \mathrm{mg}$ of potassium hydrogen phosphate $\left(\mathrm{KH}_{2} \mathrm{PO}_{4}\right), 37 \mathrm{mg}$ of potassium chloride (KCl), $200 \mathrm{mg}$ of Sequestren (Fe) and $12.5 \mathrm{ml}$ of Hoagland's B micronutrient solution (Hoagland and Snyder 1933). One liter of working solution contained distilled $\mathrm{H}_{2} \mathrm{O}$ with $100 \mathrm{ml}$ of the stock solution.

\section{Preparation of Inoculum}

Sporosorus inoculum (Table 1) was prepared from infected tubers (scrapings) and root galls (ground with a mortar and pestel). The material was soaked in $5 \mathrm{ml} \mathrm{NS}$ for $30 \mathrm{~min}$, and mixed for 2 min with a Polytron mixer (PT 2100, Kinematik AG) at 11,000 revolutions $\mathrm{min}^{-1}$. The sporosorus concentration of the four different inocula was estimated using a haemocytometer, and the inoculum suspensions were each adjusted to 500 sporosori $\mathrm{ml}^{-1}$ in a total volume of $360 \mathrm{ml}$. Inoculum preparations (Table 1) were made separately and all 
Table 1 Spongospora subterranea f. sp. subterranea sources and their assigned inoculum identity abbreviations

\begin{tabular}{llll}
\hline Inoculum origin & Host & Tissue & Inoculum ID \\
\hline Switzerland & Solanum tuberosum ssp. tuberosum & Tuber lesions & STL \\
Venezuela & Solanum tuberosum ssp. tuberosum & Tuber lesions & VTL \\
Venezuela & Solanum tuberosum ssp. andigena & Tuber lesions & VAL \\
Colombia & Solanum phureja & Root galls & CPG \\
\hline
\end{tabular}

lab equipment used was surface sterilized to avoid cross contamination.

\section{Inoculation Experiment}

The potato plants were treated with the different inocula outlined in Table 1 in a single experiment. For each treatment, six Petri dishes were prepared. These each contained $60 \mathrm{ml}$ of the sporosorus suspension and two plantlets, held by two opposite slits in the lid. For experimental controls, six Petri dishes with $60 \mathrm{ml} \mathrm{NS}$ medium (without inoculum), containing two plantlets per potato host, were prepared. The plants were cultivated in a controlled environment chamber set at a daily cycle of $18 \mathrm{C}, 16 \mathrm{~h}$ light (5 kLux) and $15 \mathrm{C}, 8 \mathrm{~h}$ dark, and $70 \%$ relative humidity. Fresh NS was regularly added (twice per week) to the Petri dishes. The severity of root galling on each test plant was assessed after 94 days, using a standard scale (http://www.spongospora.ethz.ch/LaFretaz/scoringtablegalls. htm), where: $0=$ no galls; $1=1-2$ galls; $2=3-10$ galls; $3=>10$ galls, but most in clusters; $4=$ many galls, regularly distributed over the roots. A root gall index was calculated, multiplying incidence ( $\%$ plants with galls) by the mean severity score. The severity of powdery scab infections on minitubers produced by the plants was not assessed.

\section{Molecular Methods}

Root gall and tuber lesion samples were taken from the plants for molecular analysis. The samples were freeze dried and DNA was extracted using the DNeasy Mini Plant Kit (QIAGEN) following the steps outlined by the manufacturer.

Presence of Sss DNA was confirmed using the Sss-ITSspecific Spo8 and Spo9 primer pair (Bulman and Marshall 1998). Additionally, the partial actin gene of each sample was amplified, using previously described nested PCR (Gau et al. 2013). The amplicons of both PCRs were also sequenced, using an ABI 3730xl sequencer (Applied Biosystems) and the adapted chain termination method (Sanger and Coulson 1975). Multilocus genotypes were determined to establish microsatellite profiles for all samples, as previously described (Gau et al. 2013).

Cloning of ITS fragments of the four inocula was performed with the TA cloning kit (Invitrogen). Inserts of the transformants were sequenced as decribed above, and haplotypes were determined: Completely similar sequences were considered to belong to one haplotype. Each point mutation, even in a single base pair, was considered a different haplotype. Actin fragments of the inocula were not cloned and sequenced, because they were generated in a nested PCR, which is a technique vulnerable to contamination. Furthermore, the two steps required in the nested PCR protocol could bias the results.

\section{Results}

Inoculation Experiment

Root infections (Fig. 2) developed from all four inocula, and each produced root galls. With sporosorus inoculum from Swiss tuber lesions (STL), the potato host Tu ('Agria') had consistently greater amounts of root galling compared to $T u$ treated with inoculum from Venezuelan $A n$ tuber lesions (VAL) and $T u$ tuber lesions (VTL). The smallest root gall index resulted from the Colombian $\mathrm{Pu}$ root gall (CPG) inoculum. The non-inoculated control plants were free of infection.

Gall formation occurred earlier than formation of lesions on tubers. Both diseases were enhanced when the infection sites were partially exposed to air. Galls became more obvious on the roots and stolons located above the surface of the NS (Fig. 3a), especially when NS levels in the dishes were low just before adding fresh solution. When the host plants produced small tubers with white lesions ('cauliflower' type), the addition of NS was halted to avoid immersing the infected tubers. These lesions changed into brown, wart-like structures (Fig 3b).

\section{Molecular Analyses}

Three haplotypes were found among nucleotide sequences for the actin locus and ITS region from the four inoculum sources, each of them corresponding to one of the three previously found genotype clusters for South American root gall samples (group A), South American lesion samples (group B), and root gall and lesion samples from elsewhere (group C; Table 2). Analogous results were found for the multilocus genotypes in the microsatellite profile (Table 2). None of the harvested sporosori from root galls or tuber lesions clustered with group 
Fig. 2 Average root gall indices for the Solanum tuberosum f.sp. tuberosum host (cv Agria) inoculated with Spongospora subterranea f. sp. subterranea sporosori from four sources. Each index was calculated as the product of the mean severity score and incidence of galls on roots of 12 plants. Uninoculated experimental controls were free of root galls (data not shown). Inoculum source $\left(\mathrm{X}_{1} \mathrm{X}_{2} \mathrm{X}_{3}\right)$ : Country $\left(\mathrm{X}_{1}\right): \mathrm{S}=$ Switzerland, $\mathrm{V}=$ Venezuela Host $\left(\mathrm{X}_{2}\right)$, $\mathrm{C}=$ Colombia $\left(\mathrm{X}_{3}\right)$ :

$\mathrm{T}=S$. tuberosum $\mathrm{ssp}$ tuberosum, $\mathrm{A}=S$. tuberosum $\mathrm{ssp}$ andigena, $\mathrm{P}=$ S. phureja. Sporosori from $\left(\mathrm{X}_{3}\right): \mathrm{L}=$ tuber powdery scab lesions, $\mathrm{G}=$ root galls

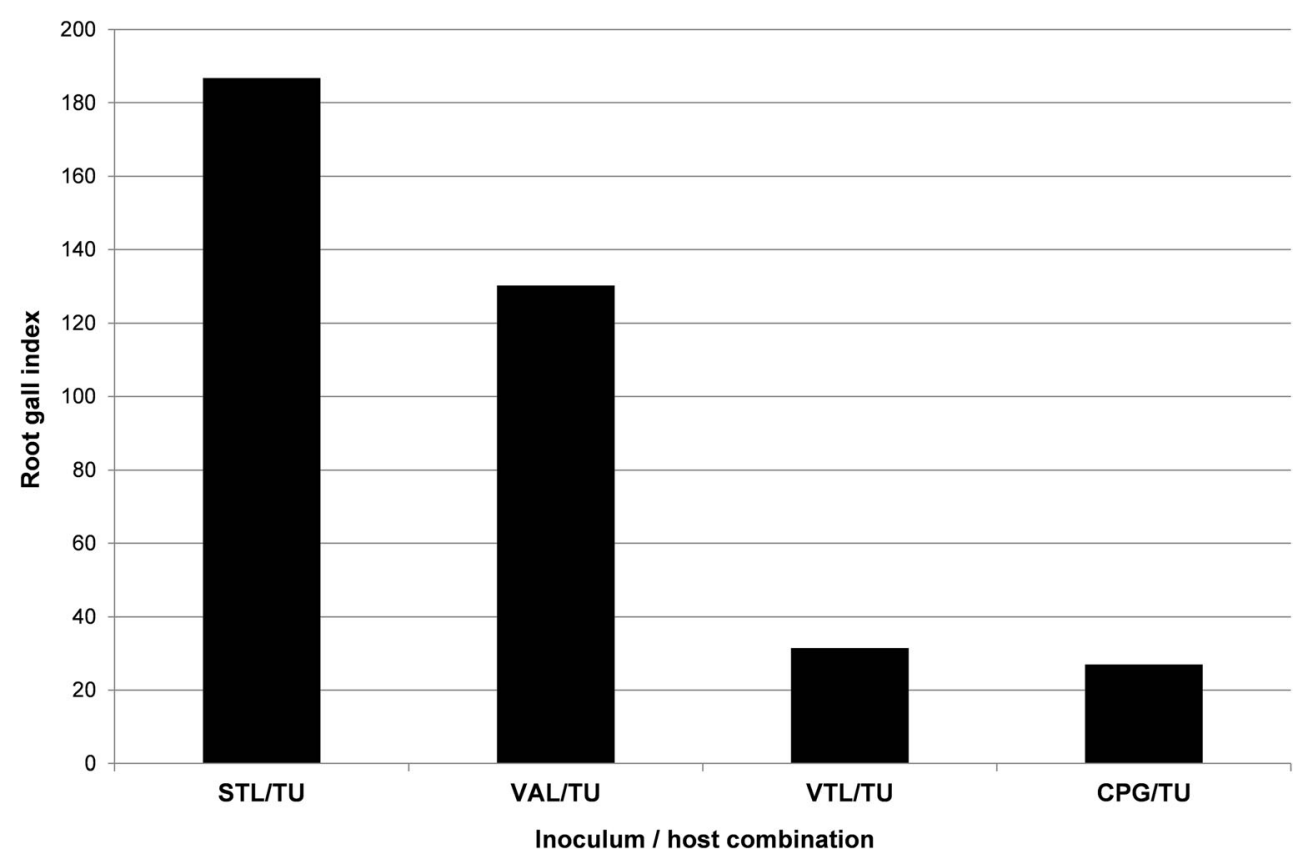

A. Harvested root gall samples of most of the combinations clustered with group $\mathrm{C}$, with one exception: The hosts treated with Venezuelan tuber lesion inoculum produced an intermediate multilocus genotype of group B and C. Genotypes of the tuber lesion samples from $T u$ treated with VTL or VAL

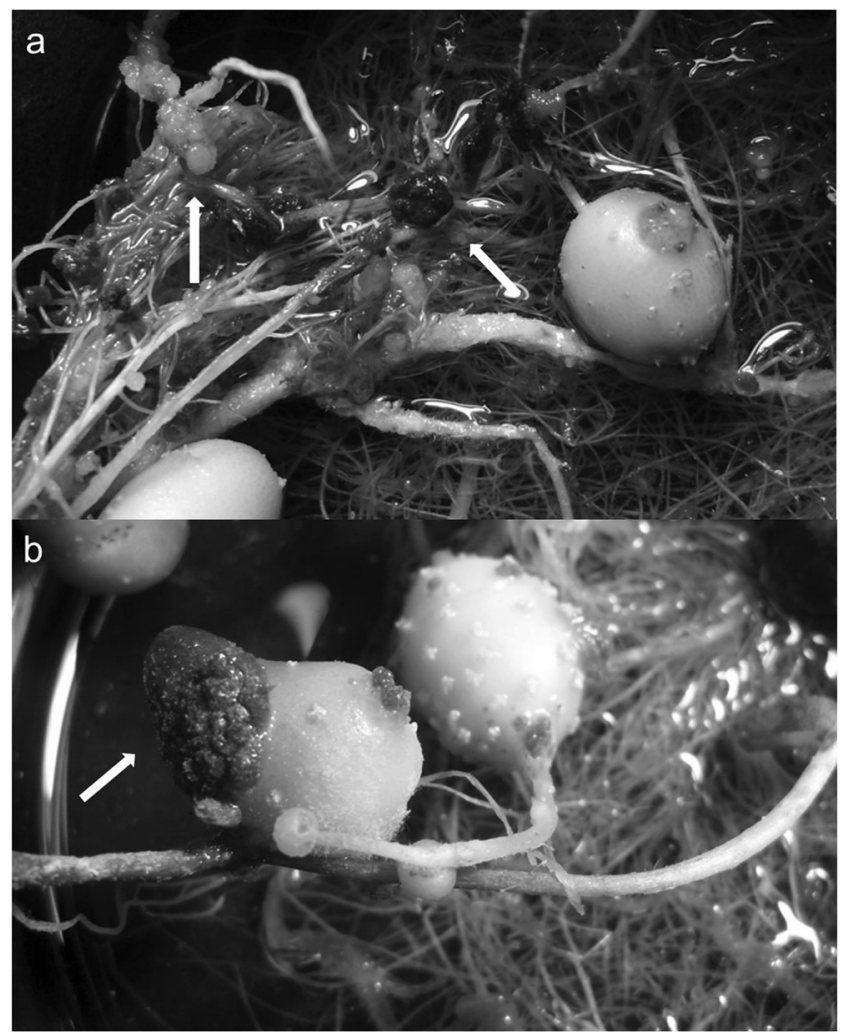

Fig. 3 Aerial root galls (a) and lesions on small tubers (b) of cv. 'Agria' potato plants inoculated with Spongospora subterranea f. sp. subterranea sporosorus inoculum in a bioassay clustered with group B (South American tuber lesion inoculum), and tuber lesion samples from $T u$ treated with STL clustered with group $\mathrm{C}$ (tuber lesion inoculum from other areas). Cloning and sequencing of ITS fragments from inocula showed that several different genotypes were present in each inoculum. The VTL inoculum was the most diverse with 17 different ITS sequences. In contrast, only three different sequences were found for the STL inoculum. Eleven were found for VAL and CPG (Fig. 4).

\section{Discussion}

This paper describes the first reported inoculation experiment with Sss inoculum from both inside and outside of South America. All inoculum-host combinations caused disease on roots, but the non-South American combination gave the greatest root gall severity. The experiment was carried out under controlled long day conditions. The bioassay used has the potential to allow root gall assessment and tuber production and infection, as well as estimation of zoosporangium root infection (Merz et al. 2004), in a hydroponic system. This protocol is therefore a useful tool for detailed evaluation of specific host-pathogen interactions for the potato/SsS pathosystem.

The long day potato host $T u$ showed susceptibility to native inocula in the experiment, which was also observed in the field trials of Torres et al. (1995) and Rodriguez et al. (2009). The infection was most severe when $T u$ was treated with Swiss tuber lesion inoculum (STL). This indicates that the susceptibility to Sss already established in Europe was 


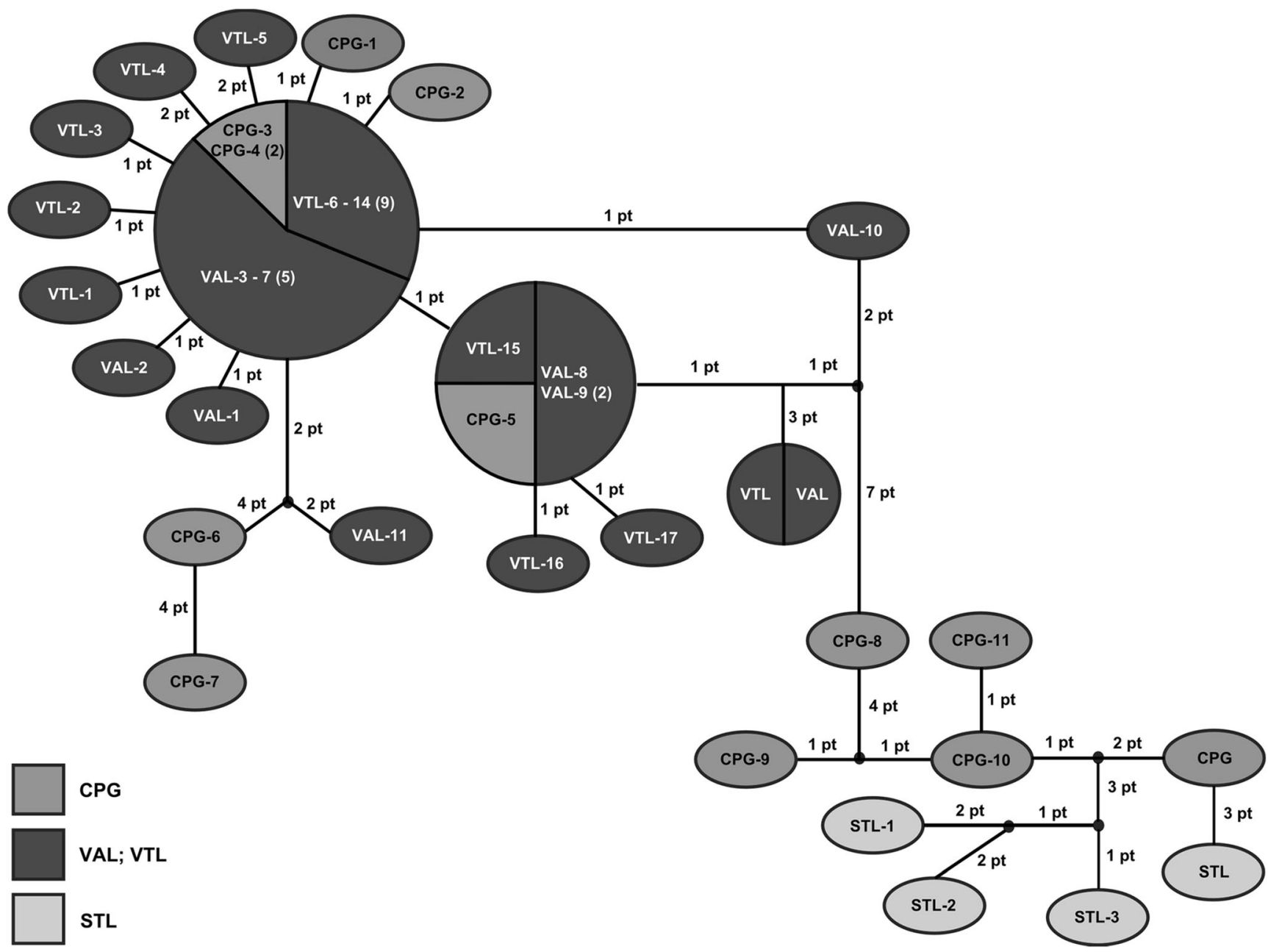

Fig. 4 Haplotype network of the ITS regions of four Spongospora subterranea $\mathrm{f}$. $\mathrm{sp}$. subterranea inoculum sources and their clones (indicated by numerals). Distances between haplotypes are expressed by the number of point mutations (pt). Inoculum source $\left(\mathrm{X}_{1} \mathrm{X}_{2} \mathrm{X}_{3}\right)$ : Country

$\left(\mathrm{X}_{1}\right): \mathrm{S}=$ Switzerland, $\mathrm{V}=$ Venezuela, $\mathrm{C}=$ Colombia. Host $\left(\mathrm{X}_{2}\right): \mathrm{T}=$ $S$. tuberosum $\mathrm{ssp}$ tuberosum, $\mathrm{A}=S$. tuberosum $\mathrm{ssp}$ andigena, $\mathrm{P}=$ S. phureja. Sporosori from $\left(\mathrm{X}_{3}\right): \mathrm{L}=$ tuber powdery scab lesions, $\mathrm{G}=$ root galls

Table 2 Genotype pattern of Spongospora subterranea f.sp. subterranea from four inoculum sources, and of sporosori from root galls and tuber lesions of the inoculated Solanum tuberosum ssp. tuberosum host 'Agria'

\begin{tabular}{|c|c|c|c|c|c|c|c|c|c|c|}
\hline \multicolumn{4}{|l|}{ Inocula } & \multirow[t]{3}{*}{ Hosts } & \multicolumn{3}{|c|}{ Galls } & \multicolumn{3}{|c|}{ Tuber lesions } \\
\hline & \multicolumn{2}{|c|}{ Haplotype } & \multirow{2}{*}{$\begin{array}{l}\text { Multilocus } \\
\text { genotype }\end{array}$} & & \multicolumn{2}{|c|}{ Haplotype } & \multirow{2}{*}{$\begin{array}{l}\text { Multilocus } \\
\text { genotype }\end{array}$} & \multicolumn{2}{|c|}{ Haplotype } & \multirow{2}{*}{$\begin{array}{l}\text { Multilocus } \\
\text { genotype }\end{array}$} \\
\hline & ITS & Actin & & & ITS & Actin & & ITS & Actin & \\
\hline $\begin{array}{l}\text { STL } \\
\end{array}$ & & & & S.t.tuberosum & & & & & & \\
\hline VTL & & & & S.t.tuberosum & & & & & & \\
\hline VAL & & & & S. t. tuberosum & & & & & & \\
\hline CPG & & & & S.t.tuberosum & & & & & & \\
\hline
\end{tabular}

South American root gall genotype (group A)

South American tuber lesion genotype (group B)

Other region gall and tuber lesion genotype (group C)

Intermediate genotype $(\mathrm{B}+\mathrm{C})$

Inoculum source $\left(\mathrm{X}_{1} \mathrm{X}_{2} \mathrm{X}_{3}\right)$ :

Country $\left(\mathrm{X}_{1}\right): \mathrm{S}=$ Switzerland, $\mathrm{V}=$ Venezuela, $\mathrm{C}=$ Colombia

Host $\left(\mathrm{X}_{2}\right): \mathrm{T}=S$. tuberosum ssp tuberosum, $\mathrm{A}=S$. tuberosum ssp andigena, $\mathrm{P}=S$. phureja

Sporosori from $\left(\mathrm{X}_{3}\right)$ : $\mathrm{L}=$ tuber powdery scab lesions, $\mathrm{G}=$ root galls 
greatest. However, there was still moderate to medium infection when $T u$ was treated with Venezuelan tuber lesion inoculum obtained from $A n$ and $T u$ hosts. This suggests that there is a risk of infection and establishment of Sss populations if new strains from South America were introduced to Europe via infected seed potatoes. The risk is confirmed by the formation of tuber lesions during the experiment. The impact of a newly introduced population on the hosts (aggressiveness) and on the already established strains of SsS (recombination) is open to speculation.

As an obligate biotroph, Sss cannot be grown on artificial media. Therefore, it is difficult to directly observe the effects of environmental factors on this pathogen. The pathogen was studied using the recently developed genetic markers, and haplotypes and genotypes of the different inocula matched the three genotype groups described by Gau et al. (2013). These were: gall samples from the South American host $P h$ (group A); tuber lesion samples from the South American host $A n$ (group B); and gall and tuber lesions samples from the host $T u$ (group C). 'Genotype shifts' occurred between infection of the host plants and harvesting of galls and lesions at the end of the experiment. Only group B inoculum caused group B root gall and tuber lesions on the 'Agria' host. In all other combinations the genotype changed.

These results are supported by the findings that all the inocula were mixtures of genotypes. In conventional PCR, just the predominant genotype is detected in a sample. Minor genotypes are detected only when the PCR products of inoculum samples are cloned, as in the present study. The apparent clonal population structure of Sss in invasive regions may be more diverse than previously reported, but in comparison to the native region, genetic variability is much less. It is possible that sexual reproduction might be the cause of increased diversity. However, only predominant genotypes have established in invasive areas, favoured by selection.

Single genotype inocula would answer this question, and $\mathrm{Qu}$ and Christ (2006) used single sporosorus inoculum to demonstrate genetic differences between North American Sss collections. A more definitive approach would be to produce root galls from inoculation experiments which incorporate genetic characterization, including cloning of inocula and harvested material. The harvested galls could be maintained using the recently described Sss callus cultures (Bulman et al. 2011) to multiply the material for repeated reinfection experiments, with recurring characterization to verify that single genotypes are achieved and maintained.

The differences between the three genetic groups of Sss could be explained by their evolutionary background. Given that Colombian Sss populations are the most diverse (Gau et al. 2013) we hypothesize that they are the most ancient among all populations tested. Group A inoculum was used in this experiment but no group A genotype has been found during genetic analyses of the products. It is likely, however, that non tuber-bearing solanaceous hosts pre-dated tuber bearing plants selected as food crops. Thus, group A could be the oldest Sss type. Group B inoculum was obtained from South American tuber lesions of $A n$ and $T u$, and this group occurs in Colombia, Venezuela and Peru (Gau et al. 2013). With the domestication of tuber-bearing solanaceous plants group B genotypes could have descended from group A. The group $\mathrm{C}$ inoculum on $T u$ caused most disease in our experiment. We suggest, that group $\mathrm{C}$ is possibly better adapted to lowland conditions (long days) and has a long evolutionary history with the $T u$ host. This may go back to the time when the edible potato was taken from its region of origin (Lake Titicaca region of Peru/Bolivia) to long-day areas by pre-Colombian sophisticated farming civilizations (FAO 2009).

It was further suggested that Sss was introduced to Europe on infected potato tubers shipped by the conquistadors in the 16th century (Gau et al. 2013), most likely as a mixture of genotypes. Under long-day conditions, group $\mathrm{C}$ individuals became dominant and spread to the rest of the world. The group C genotype still occurs in South America (Gau et al. 2013) but is less competitive in the native region, where group A and B predominate. On the other hand, our results imply that South American Sss strains may be less competitive and probably unable to establish in invasive regions. If sexual reproduction does not occur, the risk of increasing virulence by importing variable inoculum from South America may be less than previously supposed (Gau et al. 2013). Hybridization or sexual recombination between genetically different Sss strains could, however, lead to new virulent pathotypes. Increased knowledge of Sss evolution may help to predict the future development of the pathogen.

Our results suggest that pathogen genotype selection is host organ-specific, and that the most successful invasive genotype is still present in native pathogen populations. For a better understanding of the predominance of the different genotypic groups in the native and invasive region of Sss, a detailed study of South American populations is necessary. Sporosori, both from root galls and tuber lesions, should be collected from cultivated and wild solanaceous hosts. Traditional South American potato culture may introduce wild potatoes for hybridization with cultivated potatoes (FAO 2009). This could introduce new Sss genotypes from wild potatoes to fields of cultivated potatoes. Therefore, there is a need for continued strict quarantine vigilance to prevent invasions by new virulent recombinants of the pathogen, particularly from South America.

Acknowledgments This research was supported by funding from Horticulture Australia Ltd (APRP1, University of Tasmania), the ETH Zürich, the United Kingdom Potato Council, the New Zealand Ministry of Science and Innovation, Horticulture New Zealand, and the Swiss Federal Office of Agriculture. IPK Gattersleben, Germany, and Agroscope, Changins, Switzerland supplied potato plantlets. 


\section{References}

Braselton, J.P. 1995. Current status of the Plasmodiophorids. Critical Reviews in Microbiology 21: 263-275.

Bulman, S.R., and J.W. Marshall. 1998. Detection of Spongospora subterranea in potato tuber lesions using the polymerase chain reaction (PCR). Plant Pathology 47: 759-766.

Bulman, S., J.M. Candy, M. Fiers, R. Lister, A.J. Conner, and C.C. Eady. 2011. Genomics of biotrophic, plant-infecting plasmodiophorids using in vitro dual cultures. Protist 162: 449-461.

de Boer, R.F. 2000. Research into the biology and control of powdery scab of potatoes in Australia. In Proceedings of the First European Powdery Scab Workshop, SAC, Aberdeen, Scotland, 20-22 July (79-83), eds. U. Merz and A. K. Lees. http://www.spongospora. ethz.ch/EUworkshop/proceedings.html. Accessed 15 Mai 2014.

Falloon, R.E., R.A. Genet, A.R. Wallace, and R.C. Butler. 2003. Susceptibility of potato (Solanum tuberosum) cultivars to powdery scab (caused by Spongospora subterranea f. sp. subterranea), and relationships between tuber and root infection. Australasian Plant Pathology 32: 377-385.

FAO (Food and Agriculture Organization of the United Nations). 2009. International year of the potato 2008 - New light on a hidden treasure-An end of the year review. ftp://ftp.fao.org/docrep/fao/ 011/i0500e/i0500e.pdf. Accessed 15 Mai 2014.

Gau, R.D., U. Merz, R.E. Falloon, and P. Brunner. 2013. Global genetics and invasion history of the potato powdery scab pathogen, Spongospora subterranea f.sp. subterranea. PLoS ONE. doi:10. 1371/journal.pone.0067944.

Hoagland, D.R., and W.C. Snyder. 1933. Nutrition of strawberry plants under controlled conditions: a) effects of deficiencies of boron and certain other elements b) susceptibility to injury from sodium salts.
Proceedings of the American Society of Horticulture Sciences 30: 288-294.

Merz, U., and R.E. Falloon. 2009. Review: Powdery scab of potatoIncreased knowledge of pathogen biology and disease epidemiology for effective disease management. Potato Research 52: 17-37.

Merz, U., V. Martinez, and R. Schwaerzel. 2004. The potential for the rapid screening of potato cultivars (Solanum tuberosum) for resistance to powdery scab (Spongospora subterranea) using a laboratory bioassay. European Journal of Plant Pathology 110: 71-77.

$\mathrm{Qu}$, X.S., and B.J. Christ. 2006. Single cystosorus isolate production and restriction fragment length polymorphism characterization of the obligate biotroph Spongospora subterranea f.sp. subterranea. Phytopathology 98(10): 1157-1163.

Rabobank. 2009. World potato map. Utrecht: Food and Agrobusiness Research and Advisory Department, Rabobank.

Rodriguez, D., M. Ojeda, M.P. de Camacaro, M. Gallardo, R. Valera, and F. Bittara. 2009. Production, powdery scab incidence and quality of potato advanced clones. Revista de la Facultad de Agronomia de la Universidad del Zulia 26(4): 508-531.

Sanger, F., and A.R. Coulson. 1975. A rapid method for determining sequences in DNA by primed synthesis with DNA polymerase. Journal of Molecular Biology 94(3): 441-448.

Schwaerzel, R. 2002. Sensibilités des racines et tubercules des variétés de pommes de terre à la gale poudreuse et quelques résultats de lutte chimique. Revue Suisse Agricole 34: 261-266.

Shah, F., R.E. Falloon, R.C. Butler, and R.A. Lister. 2012. Low amounts of Spongospora subterranea sporosorus inoculum cause severe powdery scab, root galling and reduced water use in potato (Solanum tuberosum). Australasian Plant Pathology 41: 219-228.

Torres, H., M.A. Pacheco, and E.R. French. 1995. Resistance of potato to powdery scab (Spongospora subterranea) under andean field conditions. American Potato Journal 72: 355-363. 